Original Research Article

\title{
Positive relationship between genetic- and species diversity on limestone outcrops in the Carpathian Mountains
}

\author{
Anna Mária Csergő ${ }^{\mathrm{a}, *}$, Levente Hufnagel ${ }^{\mathrm{b}}$, Mária Höhn ${ }^{\mathrm{c}}$ \\ a Department of Botany and Biodiversity Research Centre, University of British Columbia, 2212 Main Mall, Vancouver, BC, Canada V6T $1 Z 4$ \\ ${ }^{\mathrm{b}}$ Department of Mathematics and Informatics, Corvinus University of Budapest, Villányi Str. 29-33, 1118 Budapest, Hungary \\ ${ }^{\mathrm{c}}$ Department of Botany, Corvinus University of Budapest, Ménesi Str. 44, 1118 Budapest, Hungary
}

\section{A R T I C L E IN F O}

\section{Article history:}

Received 28 July 2013

Received in revised form 11 December 2013

Accepted 2 January 2014

Available online $\mathrm{xxx}$

\section{Keywords:}

Mainland islands

Island biogeography

Intraspecific diversity

Interspecific diversity

Habitat heterogeneity

Saponaria bellidifolia

\begin{abstract}
A B S T R A C T
We asked if the genetic diversity of Saponaria bellidifolia (a habitat specialist plant) and the species diversity of its habitat are driven by parallel landscape level processes in an island-like system of limestone outcrops in the Carpathian Mountains. We tested the relationship of these two diversity levels at local and regional geographic scales. Local genetic and species diversity showed parallel patterns influenced by the number of plant communities. Likewise, at regional level there was strong evidence for parallel equilibrial dynamics of genotypes and species. However, a superimposed matrix effect enhanced the regional species diversity only. Genetic diversity of habitat specialist organisms and species diversity of these limestone outcrop islands on mainland are modulated by parallel landscape-level processes at different geographic scales, and mechanisms may be identified at very high spatial resolutions.
\end{abstract}

(C) 2014 Elsevier B.V. All rights reserved.

\section{Introduction}

Limestone outcrop systems represent strongly fragmented landscapes with high biological diversity (White and Miller, 1988). In such fragmented ecosystems, conservation biologists seek to identify valuable habitat patches that preserve elevated levels of both intraspecific and interspecific diversity (Taberlet et al., 2012). Several predictions on how these two levels of biodiversity might co-vary have emerged from landscape level models of biodiversity. The family of dynamic equilibrial models posits that coexistence of genotypes and species is driven by random colonization and extinction of species (MacArthur and Wilson, 1967; Hubbell and Foster, 1986; Hanski and Gilpin, 1997) and associated gene flow, genetic drift and speciation (Wright, 1940; Kimura, 1983). According to these models, habitat size and isolation affect immigration rate and population size, and are therefore key drivers of both genotypic and species diversity. The closely related "habitat diversity" hypothesis predicts that larger areas are environmentally more heterogeneous, which in turn promotes diversifying selection of both genotypes and species (Williams, 1964; Rosenzweig, 1995). If landscape level mechanisms act on

\footnotetext{
* Corresponding author.

E-mailaddresses: csergo@mail.ubc.ca, csergo.anna.maria@gmail.com(A.M.Csergő), leventehufnagel@gmail.com (L. Hufnagel), maria.hohn@uni-corvinus.hu (M. Höhn).
}

both genotypes and species in a similar manner, we can then hypothesize that such mechanisms may ultimately produce similar patterns of intra- and interspecific diversity (Vellend, 2005; Vellend and Geber, 2005). In support of this hypothesis, a positive relationship of genotypic and species diversity has been detected in geographically isolated ecosystems (e.g., Johannesson and André, 2006). However, a contrary result was reported when climate-driven habitat contractions caused species loss while preserving genetic diversity (Puşcaş et al., 2008), and high habitat heterogeneity favored increased abundance and genetic diversity of particular species while lowering species diversity (Odat et al., 2010) (see Vellend and Geber, 2005 for effects of habitat heterogeneity on the relationship of genetic to species diversity).

Extended models of island biogeography have incorporated a larger variety of ecological, geographical and historical factors to explain diversity patterns of isolated habitats (Lomolino, 2000; Whittaker, 2000; Heaney, 2007), thereby refocusing the research of parallel genotypic and species diversity patterns to a broader context. For example, it has been shown that diversity patterns may vary substantially across different geographic scales (Whittaker, 2000). Extinctions and drift of "sink" populations can deplete local diversity (Shmida and Wilson, 1985), but increase regional diversity of genes and species (Pulliam, 1988). Likewise, disturbance can lower local genetic and species diversity by differential survival of genes and species, but increase regional diversity (Evanno et al., 2009). 
Evidence for parallel patterns of intra- and interspecific diversity has often been expected from oceanic islands, where a sharp ecological contrast with the landscape matrix provides an ideal environment for dynamic equilibrial processes. Yet, it is not clear whether we can anticipate identical patterns in island-like habitats of mainland. While in oceanic island systems area/heterogeneity and isolation may be prime drivers of diversity, in mainland islands additional factors such as the matrix effect (Cook et al., 2002) and climate-driven habitat contractions and expansions (Puşcaş et al., 2008) further complicate the interpretation of biological patterns. Although there is accumulating theoretical and empirical support for similarity between oceanic and mainland island systems (Vellend, 2003; Vellend and Geber, 2005; Wehenkel et al., 2006; Sei et al., 2009; Lamy et al., 2013), nonsignificant (Puşcaş et al., 2008; Taberlet et al., 2012) and negative (Silvertown et al., 2009; Fady and Conord, 2010) correlations have also been reported. An important source of these contradictory results is the lack of a clear outline of the history of fragmentation and extent of habitat isolation, despite readily available frameworks (Watson, 2002). The older the fragmentation and the more pronounced the ecological contrast with the landscape matrix, the more likely the mainland habitat patches are to follow biogeographical processes typical of isolated oceanic island systems. Yet, few studies have investigated the mechanisms of coexistence of genotypes and species in such welldefined mainland island systems, despite an evident need for generalizations (Watson, 2002; Taberlet et al., 2012).

A small island-like system of limestone outcrops that represent the only localities of the rare habitat specialist plant Saponaria bellidifolia in the Apuseni Mountains (Southeastern Carpathian Mountains, Romania) is an ideal environment in which to test whether mainland islands produce parallel patterns of intra- and interspecific diversity. The outcrops consist of Triassic crystalline limestone and dolomite rocks uplifted from marine deposits during the Alpine orogeny and subsequently eroded to their current shape (Cocean, 2000). These old geological formations differ substantially from the surrounding landscape of valleys, forests and flat areas in age, geomorphology, geology, soil types and vegetation history, and therefore classify for mainland islands rather than habitat fragments. An earlier study in this system has shown a positive response of genetic diversity of $S$. bellidifolia to outcrop area/heterogeneity and isolation (Csergő et al., 2009b). The primary aim of the research reported here is to test the hypothesis that patterns of both the intraspecific- and interspecific diversity are shaped by similar landscape level mechanisms. Specifically, we tested if outcrop area, heterogeneity and isolation produced parallel patterns of genetic diversity of S. bellidifolia and species diversity of its habitat. In addition, to account for scaledependency of coexistence processes, we examined if patterns were similar at local and regional geographic scales.

\section{Materials and methods}

\subsection{Study system}

The eight South-facing limestone and dolomite outcrops studied here represent the entire area of distribution of $S$. bellidifolia in the Apuseni Mountains (Southeastern Carpathian Mountains, Romania). The outcrops are scattered on an area of less than $200 \mathrm{~km}^{2}$, ranging between 729-1382 m above sea level and $180-730 \mathrm{~m}$ above the landscape matrix; pairwise geographic distances between them are $1-13 \mathrm{~km}$. Three outcrops (Dealul Vidolm (VID), Piatra Urdaş ului (URD) and Vârful Cornului (COR)) are smaller and peripheral relative to the other five central, clustered outcrops (Scăriţa-Belioara (SC-BEL), Cheile Runcului (RUN), Cheile Pociovaliştei (POC), Pinet (PIN), Cheile Poşegii (POS)) and are spatially closer to the border between the Apuseni Mountains and the Transylvanian Plain (Fig. 1, Supporting material 1). S. bellidifolia is a very long-lived, non-clonal,

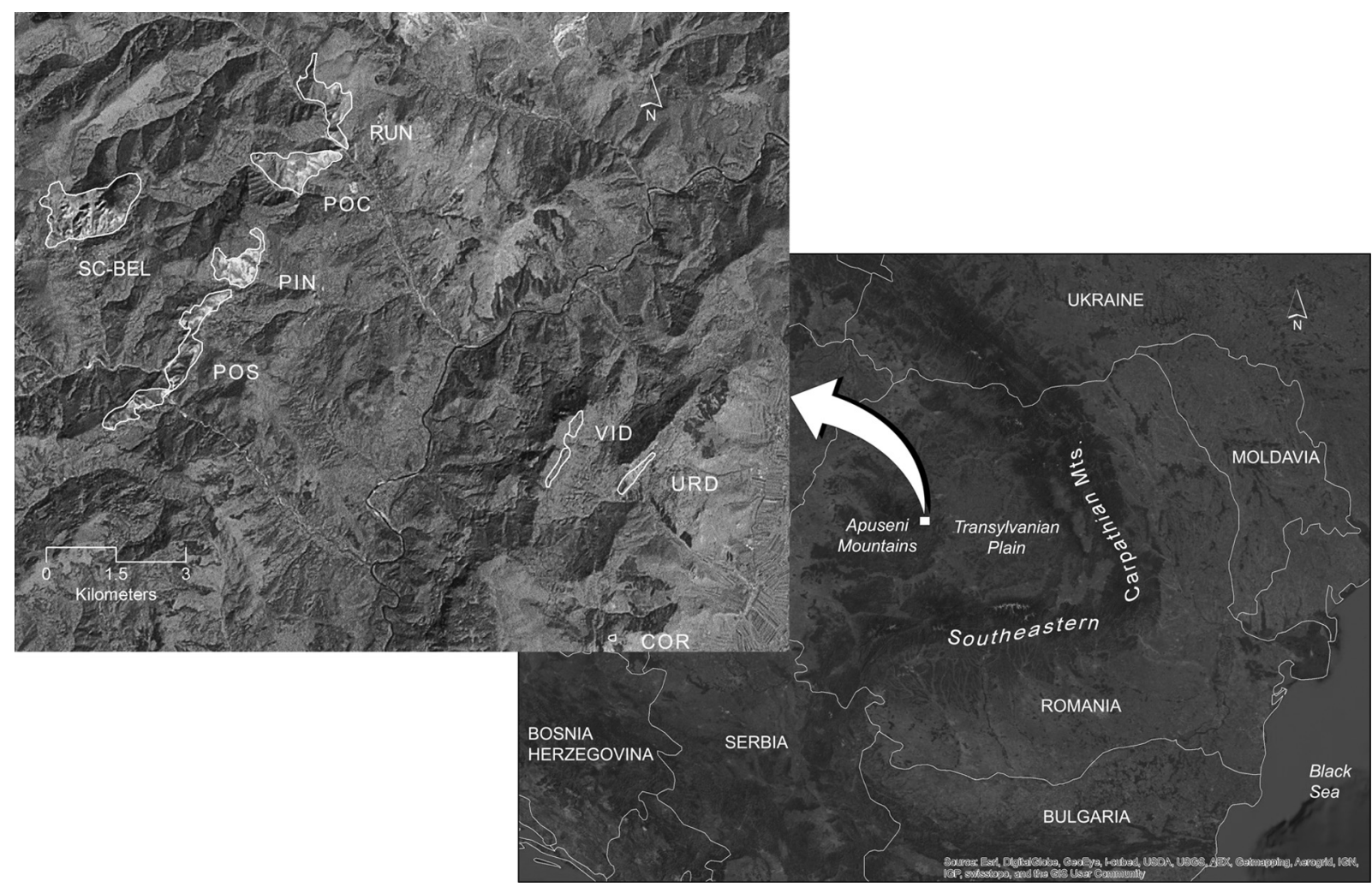

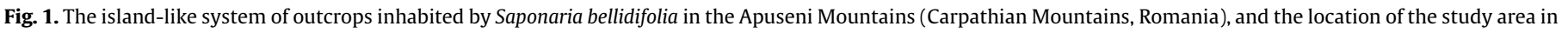
Europe. 
insect-pollinated perennial plant with limited seed dispersal ability. It is a rare habitat specialist whose local abundance is strongly affected by habitat heterogeneity and disturbance (Csergő et al., 2009a).

Supplementary material related to this article can be found, in the online version, at http://dx.doi.org/10.1016/j.ecocom.2014.01. 001.

\subsection{Sampling procedure}

In a previous RAPD-PCR study (Csergő et al., 2009b), 10 individuals were randomly sampled from seven of the eight $S$. bellidifolia outcrops described above. One site (COR) was omitted because of the small population size (six individuals). To obtain data on species diversity, semisystematic sampling was done on each outcrop along one to three horizontal transects (depending on the outcrop size), following elevation contour lines. Vegetation that was visually different was sampled in homogeneous patches in $16 \mathrm{~m}^{2}$ plots, but a few plots had $4 \mathrm{~m}^{2}, 8 \mathrm{~m}^{2}$ and $25 \mathrm{~m}^{2}$ due to topographic heterogeneity. Even sampling effort meant the number of plots ranged from 3 to 16 per location. Vascular species were identified and assigned to six cover classes (BraunBlanquet, 1964), and subsequently converted into percentages as follows: $0.5 \%, 5 \%, 17.5 \%, 37.5 \%, 62.5 \%$, and $87.5 \%$. Plant communities were identified following Coldea (1991) and the habitat type ("grassy", "rocky", "screes") was recorded for each plot. Only communities in which S. bellidifolia was usually encountered were sampled. RAPD and vegetation data available from the Dryad Digital Repository: http://doi.org/10.5061/dryad.8b3d1. Habitat heterogeneity of individual outcrops was expressed as number of plant communities, number of habitats, elevation above sea level and elevation above landscape matrix. Elevation above landscape matrix was approximated by subtracting the lowest elevation of the southern slope from the maximum elevation for each outcrop.

\subsection{Local diversity estimates}

Two local diversity measures, observed and expected diversity were used for both genotypes and species on each outcrop. Genetic diversity estimates were average RAPD band richness (a measure of observed genetic diversity) and expected heterozygosity $H_{\exp }$ (a measure of expected genetic diversity) and were based on a previous RAPD study of $10 \mathrm{~S}$. bellidifolia individuals/outcrop (Csergő et al., 2009b). The corresponding species diversity estimates were extracted from rarefaction curves computed from the presence-absence floristic matrix of each outcrop in EstimateS (Colwell, 2009), and were expressed as observed number of species (Mao Tau index) and expected number of species (Chao 2 index), respectively (Colwell, 2009; Gotelli and Chao, 2013). To ensure the comparability of species diversity estimates across habitats of unequal size, it is essential to cut off the accumulation curves at specified levels of completeness (Peterson and Slade, 1998; Watson, 2010). Therefore, in addition to adjusting our sampling effort to habitat size, we also optimized the species diversity inventory based on the precision of our results by dividing the observed species diversity (Mao Tau) by the expected species diversity (Chao 2) (Peterson and Slade, 1998), and extracted the species diversity values at $80 \%$ inventory completeness for each locality.

\subsection{Regional diversity estimates}

Regional diversity was expressed as pairwise genetic- and species composition divergence between the seven studied outcrops. Pairwise genetic distances computed based on Nei's (1978) similarities between S. bellidifolia populations were taken from Csergő et al. (2009b). Pairwise dissimilarity in species composition of $S$. bellidifolia habitat was computed from the presence-absence vegetation matrix of each outcrop using Euclidean distances. To deal with differences in the number and size of individual plots, vegetation data were standardized: first a proportional cover of each species was obtained relative to the area of individual plots, which was subsequently summed to obtain the total relative area covered by each species in each locality. Next, a species' perception threshold value was established from the lowest relative area covered by a species in the smallest habitat (URD), which was $0.03 \%$. Values below this threshold were not taken into account in the other localities. Thus random, lowabundance species on larger outcrops that would not have been sampled if the sample size (and outcrop size) was smaller were excluded from the analysis.

\subsection{Relationship of intra- and interspecific diversity}

A causal relationship between the local genetic and species diversity was not assumed, therefore, a Pearson correlation with two-tailed significance values was calculated between the estimated local genetic and species diversity values ( $\mathrm{R} 2.14 .1, \mathrm{R}$ Development Core Team).

The relationship between the two regional diversities (RAPD band dissimilarity and species composition dissimilarity) was tested with a simple Mantel test based on 1000 randomizations (MANTEL, vegan package, R 2.14.1). To visualize the differences between genetic and species composition dissimilarity, a hierarchical cluster analysis was run on the species dissimilarity matrix using the "average" clustering method (HCLUST, R 2.14.1) and the results were compared with an earlier analysis of genetic dissimilarity (Fig. 3 in Csergő et al., 2009b).

\subsection{Drivers of diversity patterns}

Previously, the effect of outcrop area on local genetic diversity estimates was assessed with simple linear regressions (Csergő et al., 2009b). Here, we tested for the effect of outcrop area and habitat heterogeneity on average RAPD band richness and expected heterozygosity $\left(H_{\text {exp }}\right)$ using linear regressions in $\mathrm{R}$ 2.14.1. In addition, we assessed the effect of outcrop area and habitat heterogeneity on observed and expected local species richness. When the assumptions of homogeneity of variances and normality of residuals were not met, data were log-or square root transformed. Because elevation and elevation above landscape matrix, and number of communities and number of habitats were highly correlated $(r>0.848, p<0.014)$, we only report the results for elevation above the landscape matrix and number of communities.

The relationship of regional genetic and species diversity to landscape parameters (geographic distance between habitats, differences in area, elevation and elevation above landscape matrix) was assessed with simple Mantel tests using R 2.14.1. In addition, partial Mantel tests were done to investigate whether landscape attributes mediated the relationship between regional diversity estimates of genes and species (MANTEL.PARTIAL, vegan package, R 2.14.1).

\section{Results}

The mainland island system studied is small, limited by the restricted geographic distribution of S. bellidifolia in the Carpathian Mountains. Although all existing $S$. bellidifolia populations, with a single exception (COR), were included in the analysis, the small number of islands makes statistical analyses prone to type II errors (ignoring true relationships). Therefore, we took much care in interpreting weaker and non-significant relationships. 


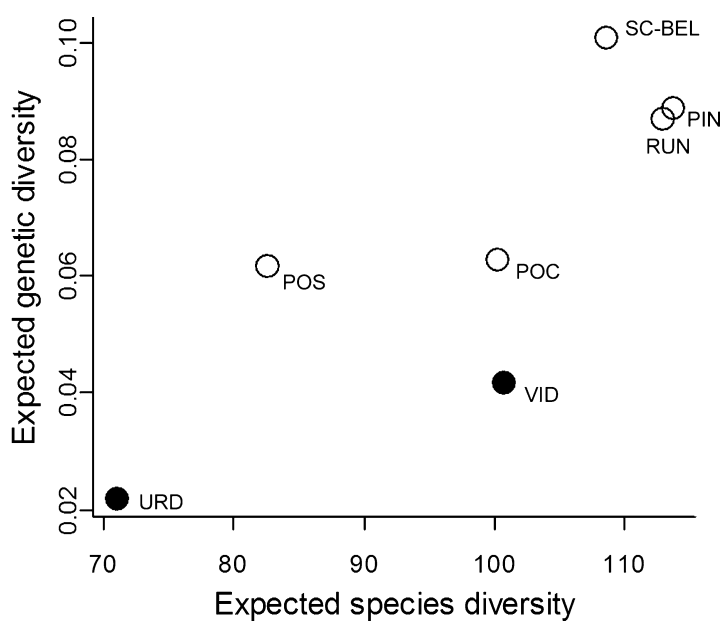

Fig. 2. The relationship between the expected genetic diversity $\left(H_{\exp }\right)$ of Saponaria bellidifolia and the expected vascular species richness (Chao 2) of its habitat. Small outcrops are shown in black.

\subsection{Local diversity of genes and species}

Average RAPD band richness was the highest in the large locality SC-BEL ( $1.25 \pm 0.4$ accumulated RAPD bands) and the lowest in the smallest population URD ( $1.05 \pm 0.2$ accumulated RAPD bands) (mean $\pm 1 \mathrm{SD}$ ) (results not shown). Likewise, expected heterozigosity $\left(H_{\text {exp }}\right)$ followed a similar pattern with values ranging between 0.101 in SC-BEL and 0.022 in URD (see Csergő et al., 2009a for more details).

The number of vegetation plots at which $80 \%$ species inventory completeness was achieved varied between 2 in the smallest habitat URD and 12 in the intermediate-sized PIN (Supporting material Fig. 1). The smallest URD habitat accumulated the lowest $(59.7 \pm 3.3 ; 70.9 \pm 5.6)$, and the largest SC-BEL habitat accumulated among highest number of observed and expected species respectively $(88.1 .2 \pm 4.1 ; 108.6 \pm 8.1)$. The intermediate-sized POS accumulated a fairly low number of observed and expected species $(63.9 \pm 3.8$; $82.6 \pm 8.2$ ) (Supporting material Fig. 2).

Supplementary material related to this article can be found, in the online version, at http://dx.doi.org/10.1016/j.ecocom.2014.01. 001.

There was a strong positive correlation between average RAPD band richness of $S$. bellidifolia populations and Mao Tau observed species richness $(n=7, r=0.746, p=0.054)$ (results not shown), and $H_{\exp }$ and Chao 2 expected species richness $(n=7, r=0.818$, $p<0.05$ ) (Fig. 2).

\subsection{Drivers of local diversity}

Outcrop area had a strong positive effect on RAPD band richness and $H_{\exp }\left(n=7, R^{2}>0.800, p<0.007\right)$ (Supporting material Fig. 3; see also Csergő et al., 2009b for details). The number of plant communities had a strong positive effect on both genetic diversity estimates ( $\left.n=7, R^{2}>0.646, p<0.029\right)$, whereas elevation above the landscape matrix did not affect genotypic diversity $(n=7$, $R^{2}<0.019, p>0.700$ (Supporting material Fig. 3).

Supplementary material related to this article can be found, in the online version, at http://dx.doi.org/10.1016/j.ecocom.2014.01. 001.

Outcrop area had a positive, albeit extremely weak effect on observed and expected species richness $\left(n=7, R^{2}<0.451\right.$, $p>0.099$ ). The number of plant communities had no effect on observed species richness $\left(n=7, R^{2}=0.364, p=0.151\right)$, and had a moderately strong positive effect on expected species richness ( $n=7, R^{2}=0.584, p=0.045$ ). As with genetic diversity, the effect of elevation above the landscape matrix was negative and not significant for either of the species richness estimates $(n=7$, $R^{2}<0.086, p>0.524$ ) (Supporting material Fig. 3).

\subsection{Regional diversity of genes and species}

Genetic dissimilarity of $S$. bellidifolia populations and community composition dissimilarity showed a significant positive correlation (Mantel test, $n=21, r=0.526, p<0.01$ ). Correspondingly, there was a high similarity between the cluster dendrograms of genetic and species composition, with the two small and peripheral populations URD and VID separated in a distinct group, and RUN and SC-BEL separated first and second within the cluster of central populations (Fig. 3a and b)

\subsection{Drivers of regional diversity}

The matrix of geographic distances was positively correlated with both the genetic $(n=21, r=0.604, p<0.01)$ and the community composition dissimilarity matrices ( $n=21, r=0.546$, $p<0.050$ ). Pairwise differences in outcrop area were positively
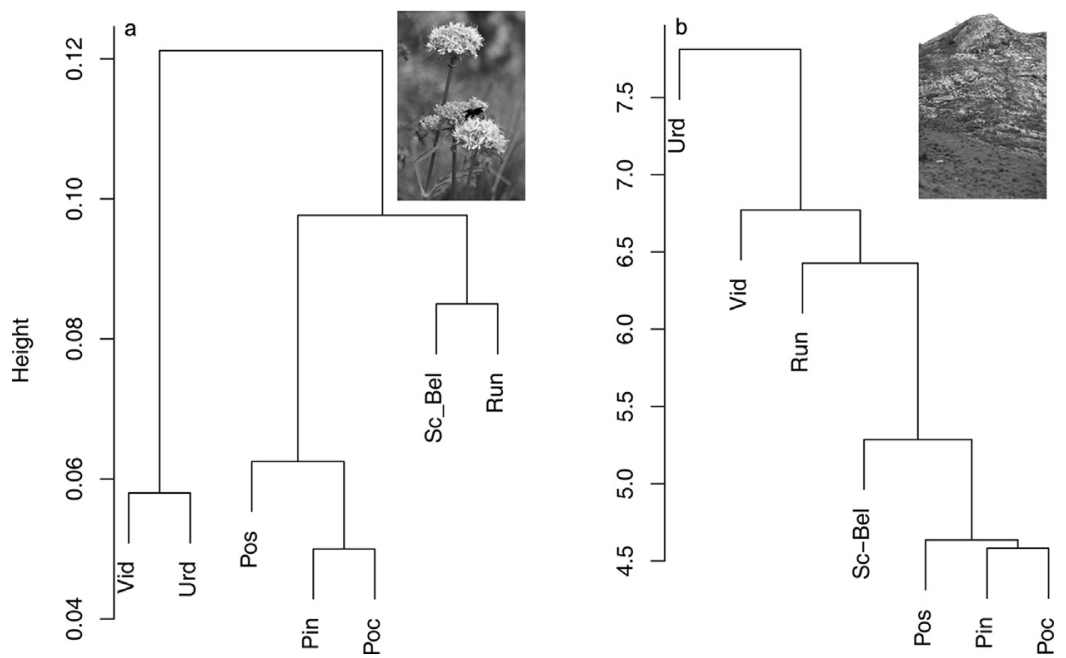

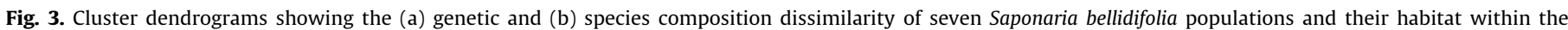
Carpathian Mountains.

(a) is modified from Csergő et al. (2009b). 
related to genetic dissimilarity of $S$. bellidifolia populations $(n=21$, $r=0.500, p<0.05$ ), but not to dissimilarity in species composition ( $n=21, r=0.202, p=0.322$ ). No significant relationship existed between differences in elevation above the landscape matrix and differences in regional genetic and species diversity $(n=21$; $r<0.346, p>0.343$ ). The positive relationship of regional diversity of genes and species was lost after controlling for geographic distance $(n=21, r=0.295, p=0.110)$ and was maintained after controlling for area and elevation above the landscape matrix (partial Mantel tests, $n=21, r>0.498, p<0.05$ ).

\section{Discussion}

\subsection{Local diversity of genes and species}

Local genetic and species diversity showed parallel patterns in this island-like system of outcrops in the Carpathian Mountains, which is an expected result in isolated mainland ecosystems (Michelangeli, 2000; Watson, 2002; Vellend, 2003; but see Puşcaş et al., 2008; Sei et al., 2009). It also appears that the intra- and interspecific diversity patterns are shaped by similar mechanisms. However, only the number of plant communities had a significant effect on both diversity levels, whereas area, albeit strong predictor of genetic diversity, was a much weaker predictor of the parallel patterns. One source of this weak relationship might consist in differences in resource availability and disturbance among outcrops that seem to have contrasting effects on individual populations. In the intermediate-sized POS site, shallow soils and frequent fires may have lowered to a great extent species diversity as also reported by Schwilk et al. (1997) and Lundholm and Larson (2003) in similar systems; in contrast, the genetic diversity of S. bellidifolia may have benefited from disturbances due to increased population patchiness (Csergő et al., 2009a).

Deviations from, or weak species diversity-area relationship such as the one described here are often reported from outcrops, where local species diversity is primarily driven by habitat heterogeneity (White and Miller, 1988; Cooper, 1997; but see Michelangeli, 2000). Our results support this view. The genetic diversity was enhanced by the number of plant communities and was probably driven by substantial differences in abundance of $S$. bellidifolia individuals under contrasting habitat conditions (Csergő et al., 2009a). Indeed, habitat patchiness may have significant effects on genetic diversity and may be a source of important evolutionary events in habitat specialists such as $S$. bellidifolia (Lönn et al., 1996). Likewise, expected species diversity increased moderately with an increasing number of plant communities. Although a larger dataset may have provided stronger statistical support to this effect, it is likely that the different types of plant communities are a good reflection of habitat heterogeneity and microhabitat processes thought to drive plant diversity on outcrops (Dufour et al., 2006; Kuntz and Larson, 2006).

Elevation was not a good predictor of either genetic or species diversity. A consistent genotypic diversity across elevational gradients was previously observed in alpine species because of compensatory mechanisms to decreased pollinator abundance at higher elevations (Thiel-Egenter et al., 2009). However, in our system a more simple process may have hindered the potential effects of elevation differences among outcrops on genetic diversity of $S$. bellidifolia. First, as opposed to high alpine systems, on montane outcrops the elevational gradient is relatively short. Second, the species is confined to the southern, warm slopes on each outcrop and is more abundant in the upper half of the outcrops, and consequently it might experience similar microclimates within each locality regardless of outcrop height. In contrast, increased species diversity at higher elevations was often reported on limestone outcrops due to additional cold-tolerant species (White and Miller, 1988), yet it is still not true for the $S$. bellidifolia habitat because both the least diverse (URD) and one of the most diverse outcrops (SC-BEL) had high elevation. This suggests that on montane outcrops such as those studied here topographic heterogeneity may be stronger driver of genetic- and species diversity patterns.

\subsection{Regional diversity of genes and species}

Similarly to the local diversity, regional genetic- and species diversity were positively related. Such co-varying patterns at a regional level have been reported before from isolated mainland ecosystems (Sei et al., 2009). The parallel patterns were produced mainly by geographic distance, which lends support to neutral forces shaping the diversity of genes and species in this system. Remote islands theoretically have a low ability to capture propagules, and as a result their genetic and species pool may diverge due to an incomplete set of genotypes and species. In $S$. bellidifolia, the genotypes likely followed this regional dynamic, because the two peripheral populations contained a small subset of the genetic diversity of the larger populations (details in Csergö et al., 2009b). One source of this mechanism typical to oceanic islands is the low dispersal ability and high habitat specialization of this plant species. The seeds lack a dispersal apparatus and jump dispersal events (e.g., by herbivores that forage on multiple islands) are probably rare. Compared with habitat generalists, specialist species of mainland islands such as $S$. bellidifolia are exposed to dispersal challenges similar to organisms on oceanic islands, and as a result are more likely to meet the predictions of dynamic equilibrium models (Dupré and Ehrlén, 2002).

Community composition similarity also declined with distance, suggesting that limestone grassland species on outcrops follow neutral dispersal mechanisms similar to the genotypes of $S$. bellidifolia. But, as with the local diversity, outcrop area was not associated with regional diversity patterns, which reinforces the minor role of this parameter in shaping species diversity on limestone outcrops. Instead, a landscape matrix effect (Cook et al., 2002) appeared to enhance the species turnover among outcrops. The system bordered two different types of landscape, and the small peripheral islands captured unique species from the Transylvanian Plain (e.g., Artemisia lobelii), whereas the central larger islands shared unique species with the Apuseni Mountains (e.g., Gentiana clusii). Consequently, the studied limestone outcrops were not completely isolated and appeared to share some of the ecological conditions and species with the adjacent landscape matrix. Indeed, the biogeographic history of these low elevation limestone outcrops had episodes of invasion during climate-driven plant migrations from the neighboring plains, which likely had a larger effect on the small peripheral habitats (review in Borhidi, 1997; Bădărău et al., 1998). Thus, it appears that the matrix effect is frequent on limestone outcrops despite their pronounced geomorphological individuality, in sharp contrast with true oceanic islands. If landscape matrices that contain individual islands have very different species pools, as in our system, they ultimately enhance the species composition dissimilarity of these mainland islands. In such cases, the causes of parallel patterns of regional genetic and species diversity are not entirely identical, and are not similar to processes on oceanic island systems.

\section{Conclusion}

The outstanding species richness of limestone outcrops has been long recognized. This study has shown that outcrop islands may represent both hotspots of species diversity and important evolutionary laboratories for calcareous grassland specialist species. 
The number of plant communities was a common driver of local genetic- and species diversity patterns in this system, which highlights the importance of local scenes for generating biodiversity on limestone outcrops. In addition, the strong evidence for parallel equilibrial dynamics of genes and species suggests that geographic distance is a particularly important source of genetic and species turnover in these habitats. A significant portion of diversity may emerge in the mainland archipelago as a whole, and individual islands may bring unique contributions to the regional genetic- or species pools.

Both the environmental and equilibrial mechanisms described in this study showed a high similarity of mainland outcrop islands with true oceanic islands, which underlines the pronounced ecological individuality of these special habitats. However, the matrix effect exists, and the number of coexisting species may ultimately depend on unaltered ecological links with the neighboring landscape.

Finally, the parallel patterns of genetic and species diversity emerged at both local and regional geographic scales despite the fact that the studied system was spatially restricted. Therefore, in limestone outcrop systems it is possible to detect common drivers of intra- and interspecific diversity at very high spatial resolutions.

\section{Acknowledgements}

We thank Mihai Puşcaş for useful discussions, Mark Vellend for support with data analysis, Roy Turkington and his lab at the University of British Columbia and Annika Noreen for comments and edits to previous versions of the manuscript. We are indebted to David M. Watson and the anonymous reviewers whose comments considerably improved the quality of the manuscript.

\section{References}

Bădărău, A., Oncu, M., Peştina, C., Puşcaş, A., 1998. Considerations about the biogeographical features of the low altitude calcareous massifs within the Carpathians. Studia Univ. Babeș-Bolyai. Geographia 43, 65-68.

Borhidi, A., 1997. Thoughts and doubts: the Ösmátra-theory. In: Szabó, L. (Ed.), Studia Phytologica Jubilaria, Pécs. pp. 161-188.

Braun-Blanquet, J., 1964. Pflanzensoziologie. Grundzge der Vegetationskunde. Springer Verlag, Wien.

Cocean, P., 2000. Munţii Apuseni - Procese şi forme carstice. Ed. Acad. R., p. 253.

Coldea, G., 1991. Prodrome des associations végétales des Carpates du Sud-Est (Carpates Roumaines). Doc. Phytosociol. 13, 317-539.

Colwell, R.K., 2009. EstimateS: statistical estimation of species richness and shared species from samples. Version 8.2. User's Guide and application published at: http://purl.oclc.org/estimates.

Cook, W.M., Lane, K.T., Foster, B.L., Holt, R.D., 2002. Island theory, matrix effects and species richness patterns in habitat fragments. Ecol. Lett. 5, 619-623, http:// dx.doi.org/10.1046/j.1461-0248.2002.00366.x.

Cooper, A., 1997. Plant species coexistence in cliff habitats. J. Biogeogr. 24, 483-494, http://dx.doi.org/10.1111/j.1365-2699.1997.00128.x.

Csergő, A.M., Nemes, S., Gafta, D.C., Demeter, L., Jakab, S., 2009a. Two-scale modelling of Saponaria bellidifolia Sm (Caryophyllaceae) abundance on limestone outcrops from its northern range periphery (Southeastern Carpathians). Plant Ecol. 203, 229-242, http://dx.doi.org/10.1007/s11258-008-9539-2.

Csergő, A.M., Schönswetter, P., Mara, G., Deák, T., Boscaiu, N., Höhn, M., 2009b. Genetic structure of peripheral, island-like populations: a case study of Saponaria bellidifolia Sm (Caryophyllaceae) from the Southeastern Carpathians. Plant Syst. Evol. 278, 33-41, http://dx.doi.org/10.1007/s00606-008-0129-5.

Dupré, C., Ehrlén, J., 2002. Habitat configuration, species traits and plant distributions. J. Ecol. 90, 796-805, http://dx.doi.org/10.1046/j.1365-2745.2002.00717.x.

Dufour, A., Gadallah, F., Wagner, H.H., Guisan, A., Buttler, A., 2006. Plant species richness and environmental heterogeneity in a mountain landscape: effects of variability and spatial configuration. Ecography 29, 573-584, http://dx.doi.org/ 10.1111/j.0906-7590.2006.04605.x.

Evanno, G., Castella, E., Antoine, C., Paillat, G., Goudet, J., 2009. Parallel changes in genetic diversity and species diversity following a natural disturbance. Mol. Ecol. 18, 1137-1144, http://dx.doi.org/10.1111/j.1365-294X.2009.04102.x.

Fady, B., Conord, C., 2010. Macroecological patterns of species and genetic diversity in vascular plants of the Mediterranean basin. Divers. Distrib. 16, 53-64, http:// dx.doi.org/10.1111/j.1472-4642.2009.00621.x.

Gotelli, N.J., Chao, A., 2013. Measuring and estimating species richness, species diversity and biotic similarity from sampling data. In: Levin, S.A. (Ed.), Encyclopedia of Biodiversity, second ed., vol. 5. Academic Press, Waltham, MA, pp. 195-211.
Hanski, I.A., Gilpin, M.E., 1997. Metapopulation Biology. Ecology, Genetics and Evolution. Elsevier Science, San Diego.

Heaney, L.R., 2007. Is a new paradigm emerging for oceanic island biogeography? J Biogeogr. 34, 753-757, http://dx.doi.org/10.1111/j.1365-2699.2007.01692.x.

Hubbell, S.P., Foster, R.B., 1986. Biology, chance and history and the structure of tropical rain forest tree communities. In: Diamond, J., Case, T.J. (Eds.), Community Ecology. Harper and Row, New York, pp. 314-329.

Johannesson, K., André, C., 2006. Life on the margin: genetic isolation and diversity loss in a peripheral marine ecosystem, the Baltic Sea. Mol. Ecol. 15, 2013-2029, http://dx.doi.org/10.1111/j.1365-294X.2006.02919.x.

Kimura, M., 1983. The Neutral Theory of Molecular Evolution. Cambridge University Press, Cambridge.

Kuntz, K.L., Larson, D.W., 2006. Microtopographic control of vascular plant, bryophyte and lichen communities on cliff faces. Plant Ecol. 185, 239-253, http:// dx.doi.org/10.1007/s11258-006-9101-z.

Lamy, T., Jarne, P., Laroche, F., Pointier, J.-P., Huth, G., Segard, A., David, P., 2013. Variation in habitat connectivity generates positive correlation between species and genetic diversity in a metacommunity. Mol. Ecol. 22, 4445-4456, http:// dx.doi.org/10.1111/mec.12399.

Lomolino, M.V., 2000. A call for a new paradigm of island biogeography. Glob. Ecol Biogeogr. 9, 1-6, http://dx.doi.org/10.1046/j.1365-2699.2000.00185.x.

Lundholm, J.T., Larson, D.W., 2003. Relationships between spatial environmental heterogeneity and plant species diversity on a limestone pavement. Ecography 26, 715-722, http://dx.doi.org/10.1111/j.0906-7590.2003.03604.x.

Lönn, M., Prentice, H.C., Bengtsson, K., 1996. Genetic structure, allozyme-habitat associations and reproductive fitness in Gypsophila fastigiata (Caryophyllaceae). Oecologia 106, 308-316, http://dx.doi.org/10.1007/BF00334558.

MacArthur, R.H., Wilson, E.O., 1967. The Theory of Island Biogeography. Princeton University Press, Princeton.

Michelangeli, F.A., 2000. Species composition and species-area relationships in vegetation isolates on the summit of a sandstone mountain in southern Venezuela. J. Trop. Ecol. 16, 69-82.

Nei, M., 1978. Estimation of average heterozygosity and genetic distance from a small number of individuals. Genetics 89, 583-590.

Odat, N., Hellwig, F.H., Jetschke, G., Fischer, M., 2010. On the relationship between plant species diversity and genetic diversity of Plantago lanceolata (Plantaginaceae) within and between grassland communities. J. Plant Ecol. 3, 41-48, http://dx.doi.org/10.1093/jpe/rtp017.

Peterson, A.T., Slade, N.A., 1998. Extrapolating inventory results into biodiversity estimates and the importance of stopping rules. Divers. Distrib. 4 (3) 95-105 http://dx.doi.org/10.1046/j.1365-2699.1998.00021.x.

Pulliam, H., 1988. Sources, sinks, and population regulation. Am. Nat. 132, 652-661 http://dx.doi.org/10.1086/284880.

Puscas, M., Taberlet, P., Choler Ph, 2008. No positive correlation between species and genetic diversity in European alpine grasslands dominated by Carex curvula. Divers. Distrib. 14, 852-861, http://dx.doi.org/10.1111/j.1472-4642.2008 00489.x.

R Development Core Team, 2011. R: A Language and Environment for Statistical Computing. R Foundation for Statistical Computing, Vienna, Austria. http:// www.R-project.org/

Rosenzweig, M.L., 1995. Species Diversity in Space and Time. Cambridge Univ. Press, Cambridge.

Schwilk, D.W., Keeley, J.E., Bond, W.J., 1997. The intermediate disturbance hypothesis does not explain fire and diversity pattern in fynbos. Plant Ecol. 132, 77-84, http://dx.doi.org/10.1023/A:1009755320731.

Sei, M., Lang, B., Berg, D.J., 2009. Genetic and community similarities are correlated in endemic-rich springs of the northern Chihuahuan Desert. Glob. Ecol. Bio geogr. 18, 192-201, http://dx.doi.org/10.1111/j.1466-8238.2008.00436.x.

Shmida, A., Wilson, M., 1985. Biological determinants of species diversity. J. Biogeogr. 12, 1-20, http://dx.doi.org/10.2307/2845026.

Silvertown, J., Biss, P.M., Freeland, J., 2009. Community genetics: resource addition has opposing effects on genetic and species diversity in a 150-year experiment. Ecol. Lett. 12, 165-170, http://dx.doi.org/10.1111/j.1461-0248.2008.01273.x.

Taberlet, P., et al., 2012. Genetic diversity in widespread species is not congruent with species richness in alpine plant communities. Ecol. Lett. 15, 1439-1448, http://dx.doi.org/10.1111/ele.12004.

Thiel-Egenter, C., Gugerli, F., et al., 2009. Effects of species traits on the genetic diversity of high-mountain plants: a multi-species study across the Alps and the Carpathians. Glob. Ecol. Biogeogr. 18, 78-87, http://dx.doi.org/10.1111/ j.1466-8238.2008.00421.x.

Vellend, M., 2003. Island biogeography of genes and species. Am. Nat. 162, 358-365, http://dx.doi.org/10.1086/377189.

Vellend, M., 2005. Species diversity and genetic diversity: parallel processes and correlated patterns. Am. Nat. 166, 199-215, http://dx.doi.org/10.1086/431318.

Vellend, M., Geber, M.A., 2005. Connections between species diversity and genetic diversity. Ecol. Lett. 8, 767-781, http://dx.doi.org/10.1111/j.1461-0248.2005. 00775.x.

Watson, D.M., 2002. A conceptual framework for studying species composition in fragments, islands and other patchy ecosystems. J. Biogeogr. 29, 823-834 http://dx.doi.org/10.1046/j.1365-2699.2002.00726.x.

Watson, D.M., 2010. Optimizing inventories of diverse sites: insights from Barro Colorado Island birds. Methods Ecol. Evol. 1, 280-291, http://dx.doi.org/ 10.1111/j.2041-210X.2010.00028.X.

Wehenkel, C., Bergmann, F., Gregorius, H., 2006. Is there a trade-off between species diversity and genetic diversity in forest tree communities? Plant Ecol. 185 151-161, http://dx.doi.org/10.1007/s11258-005-9091-2. 
Williams, C.B., 1964. Patterns in the Balance of Nature: And Related Problems in Quantitative Ecology. Academic Press, New York.

White, P.S., Miller, R.I., 1988. Topographic models of vascular plant richness in the southern Appalachian high peaks. J. Ecol. 76, 192-199, http://dx.doi.org/ $10.2307 / 2260463$.
Whittaker, R.J., 2000. Scale, succession and complexity in island biogeography: are we asking the right questions? Glob. Ecol. Biogeogr. 9, 75-85, http://dx.doi.org/ 10.1046/j.1365-2699.2000.00200.x.

Wright, S., 1940. Breeding structure of populations in relation to speciation. Am. Nat. 74, 232-248, http://dx.doi.org/10.1086/280891. 